\title{
Evaluation of porous vitreous carbon or silicon implants by radiology in rat's skull ${ }^{1}$
}

\author{
Avaliação radiológica de implantes de carbono vítreo poroso ou silicone em crânio de \\ ratos
}

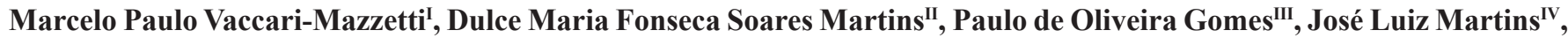 \\ Paulo Fabiani $^{\text {, }}$ Célio Toshiro Kobata ${ }^{\text {II }}$

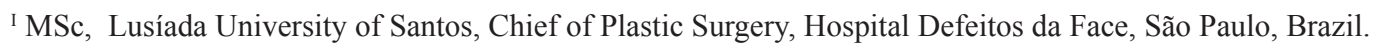 \\ ${ }^{\text {II }} \mathrm{PhD}$, Associate Professor, Department of Surgery, Division of Plastic Surgery, UNIFESP, São Paulo, Brazil, \\ III PhD, Associate Professor, Department of Surgery, Division of Operatory Technique and Experimental Surgery. UNIFESP, São Paulo, Brazil. \\ Iv PhD, Associate Professor, Department Surgery, Division of Pediatric Surgery, UNIFESP, São Paulo, Brazil. \\ ${ }^{v}$ Assistant Professor, Department of Radiology, Lusíada University of Santos, Brazil.

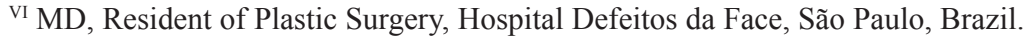

\begin{abstract}
Purpose: Evaluate by CT the use of porous vitreous carbon (PVC) and silicon (S) implants as the replacement bone in the craniofacial skeleton of rats. Methods: 40 rats divided in: Group A ( $n=20)$ PVC submitted to the implant of a fragment in skull. After the euthanasia, the animals were divided into two subgroups: A I: 10 animals, studied in the 7th postoperative day (P.O) and AII: 10 animals, studied in the 28th P.O. In group B, S, 20 rats were submitted to S implant in the skull. All other steps were identical to group A, with designation of subgroups BI and BII. CT with beams in axial cuts of 1 mm thickness to obtain 3-D information It was used Hounsfield scale for evaluate the radio density of the implant. They were used non parametric tests to analyze the results. Results: The 7th PO boss remained in the two groups, but for 28th PO, observed reduction in the volume of the implant in Group A, not observed in group B. CT studies noticed different radio densities around all of S prostheses (pseudocapsule), that don't appeared in CPV implants. The S has remained unchanged in the CT, but the CPV has had a modification in its radio density $(\mathrm{p} \leq 0,05)$, in all implants. Conclusion: In CT evaluation the implants of CPV have greater deformation that the S, which makes them not suitable for replacement of membranous bone in the rat skull.
\end{abstract}

Key words: Craniofacial, surgery. Carbon. Silicon. Rats.

\section{RESUMO}

Objetivo: Realizar avaliação através de tomografia computadorizada (TC) de implantes de carbono vítreo poroso (CVP) e silicone (S) para sua utilização na substituição óssea no esqueleto craniofacial de ratos. Métodos: Foram utilizados 40 ratos Wistar divididos em: Grupo A ( $\mathrm{n}=20)$, implantes subperiostais de CVP no crânio. Após o momento da eutanásia os animais foram divididos em dois subgrupos: A I: 10 animais, estudados no $7^{0}$ dia pós-operatório (PO) e AII: 10 animais, estudados no $28^{0}$ PO. No grupo B ( $\mathrm{n}=20)$, os ratos foram submetidos ao implante de silicone no crânio. Todas outras etapas foram idênticas ao grupo A, com a designação de subgrupos BI e BII. Foi realizada tomografia computadorizada com cortes axiais de $1 \mathrm{~mm}$ de espessura para obtenção de imagens tridimensionais. A escala de Hounsfield foi utilizada para avaliação da radiodensidade dos implantes. Testes estatísticos não paramétricos foram utilizados para analisar os resultados. Resultados: $\mathrm{O}$ volume do implante foi mantido ao $7^{0}$ PO nos dois grupos, mas ao $28^{\circ} \mathrm{PO}$, ocorreu uma redução no volume do implante no grupo A, não observada no grupo B. Os estudos tomográficos demonstraram a presença de uma pseudo-cápsula ao redor dos implantes no grupo $\mathrm{B}$, não observada nos implantes de CVP. Os implantes de silicone permaneceram inalterados na TC, mas os de CVP apresentaram modificação na sua radiodensidade e deformação $(\mathrm{p} \leq 0,05)$. Conclusão: Na avaliação, através de $\mathrm{TC}$, os implantes de CPV apresentam maior deformação que os de $\mathrm{S}$, o que os torna inadequados para substituição do osso membranoso no crânio de ratos.

Descritores: Craniofacial, cirurgia. Carbono. Silicone. Ratos.

1. Research performed at Operatory Technique and Experimental Surgery Division, Department of Surgery, Federal University of São Paulo (UNIFESP) and Lusíada University of Santos, Brazil. 


\section{Introduction}

The plastic surgery of the craniofacial skeleton presents challenges as the loss of bone substance in large quantities. These deficiencies can be used distraction ostegenesis, in addition to self-grafts and biomaterials ${ }^{1,2,3}$.

The self-graft is the first choice, but does not apply to areas very extensive due to the morbidity of the donor area and the possibility of no restoration of graft free. In these cases, the biomaterials should be considerate ${ }^{2-4}$.

Porous vitreous carbon can be used in craniomaxillofacial surgery, in the manufacture of orthopedic implants, dental, heart valves, and other procedures ${ }^{4}$.

The silicon, a polymer biomaterial, is one of the most used because it presents low reaction. This fact has caused some authors consider it without tissue reaction ${ }^{5}$.

The interest of the authors in carbon and silicon corresponded to their uses in craniomaxillofacial surgery to replace the bone, with the advantages of coming to the material biocompatibility autogenous ${ }^{6-8}$.

We did not find comparative studies in the literature between the porous vitreous carbon and silicon fills to the craniofacial skeleton.

The purpose of this study was to evaluate the use of porous vitreous carbon and silicon implants as the replacement bone in the craniofacial skeleton, studying the reaction of tissue implants membranous bone in the skull of rats, from the radiological point of view.

\section{Methods}

This study was approved by the Committee on Ethics in Research of the UNIFESP / EPM and ratified by the Commission for Research of Lusíada University (Medical School of Santos), follow the Council for International Organization of Medical Sciences (CIOMS) and ethical code for animal experimentation.

Forty rats were used (Rattus novergicus albinus), Wistar EPM line, male, with an average age of four months, average weight of 390 grams, from the Central Bioterium (CEDEME) of the UNIFESP (Figure 1).

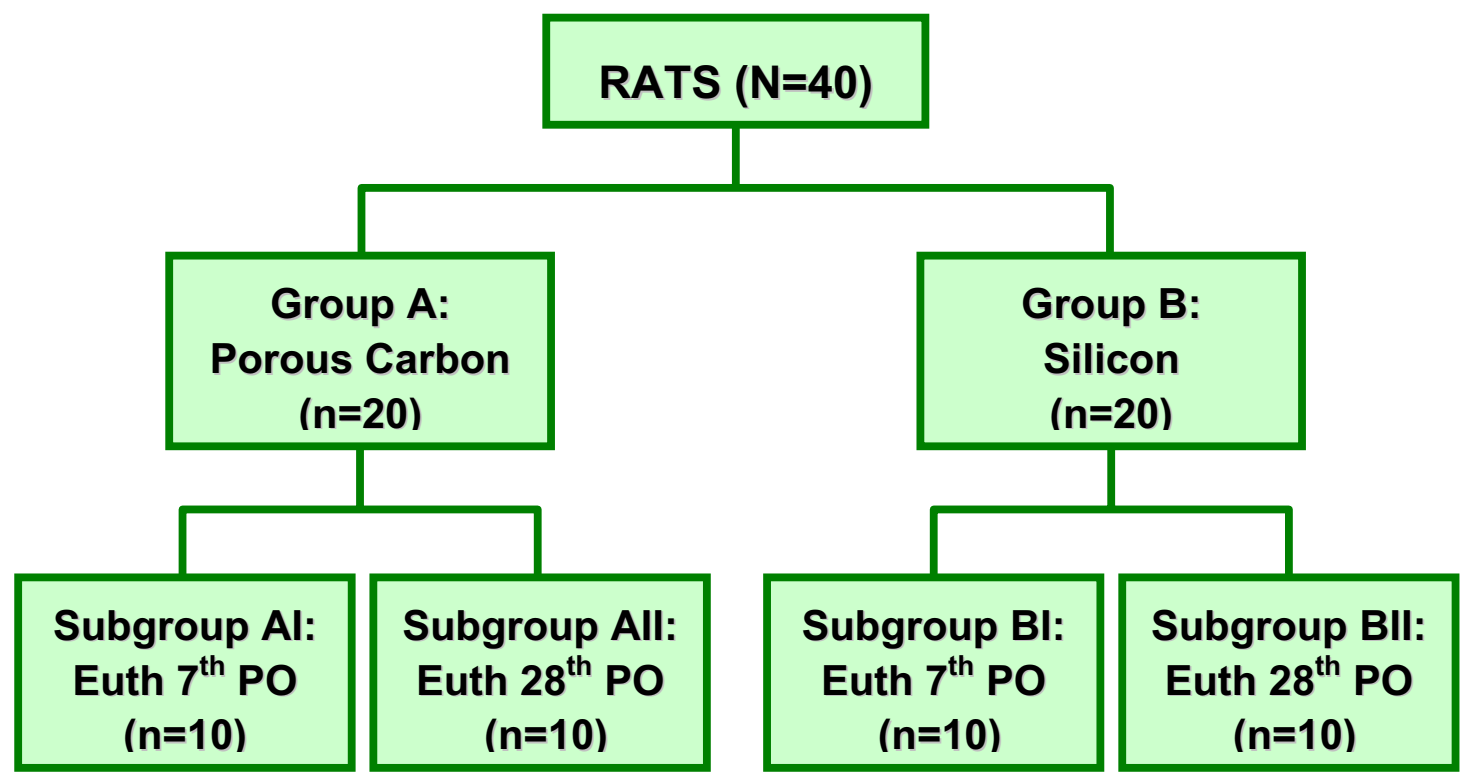

FIGURE 1 - Animals distribution in different study groups

The animals were kept in individual plastic cages, with $40 \mathrm{~cm}^{3}$, identified, staying for seven days prior to the completion of the experiment, with purpose of adaptation. The temperature was controlled by the air conditioning system, the light from the light-dark cycle of twelve hours, acoustic isolation, and standardized feed for laboratory animals (rats and mice) and water ad libitum.

The carbon used was of the type porous vitreous and the silicon was solid.

The animals were distributed in: Group A-porous vitreous carbon, twenty rats were submitted to the implant of a fragment of $0.64 \mathrm{~cm}^{2}$ porous ( $8 \mathrm{~mm} \mathrm{x} 8 \mathrm{~mm}$ and $6 \mathrm{~mm}$ thick), carbon (Figure 2) in skull without periosteum; after this procedure the synthesis of the wound was performed and the animal was sent to the IGC in the immediate postoperative period.

As the period of euthanasia, the animals were divided into two subgroups: subgroup AI: 10 animals, studied in the 7th postoperative day (P.O) and subgroup IIA: 10 animals, studied in the 28th P.O.

In group $\mathrm{B}$, silicon, twenty rats were submitted to the implant via affixing of a fragment of $0.64 \mathrm{~cm}^{2}(8 \mathrm{~mm} \times 8 \mathrm{~mm}$ and $8 \mathrm{~mm}$ thick) of silicon (Figure 2), in the skull, without periosteum of the animal. All other steps were identical to group A, with designation of subgroups BI and BII. 


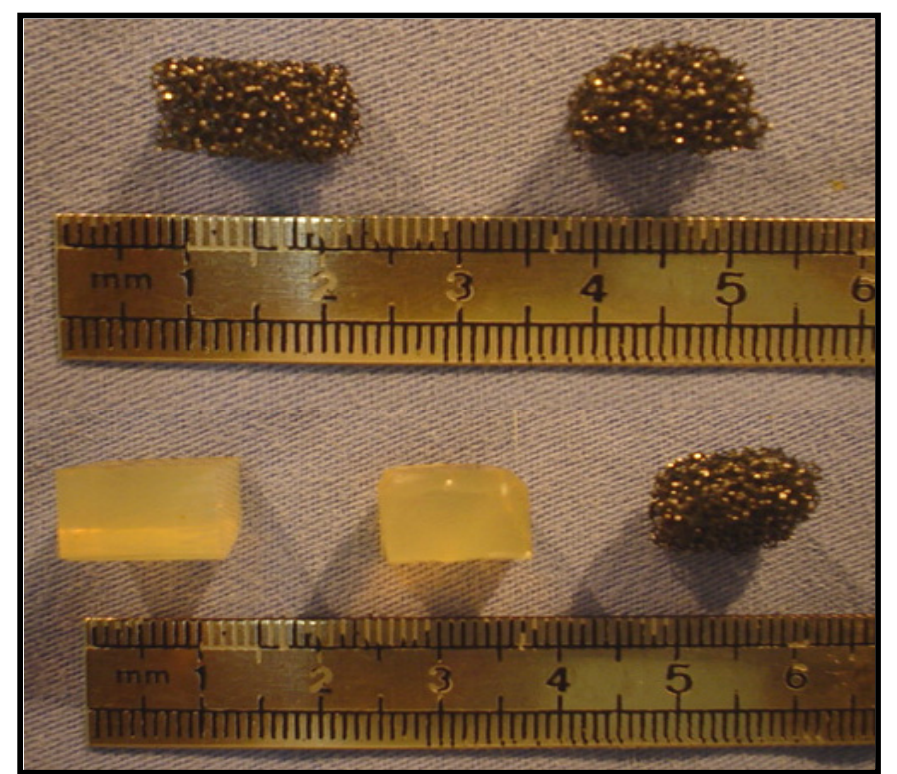

FIGURE 2 - Porous vitreous carbon and silicon used for implant
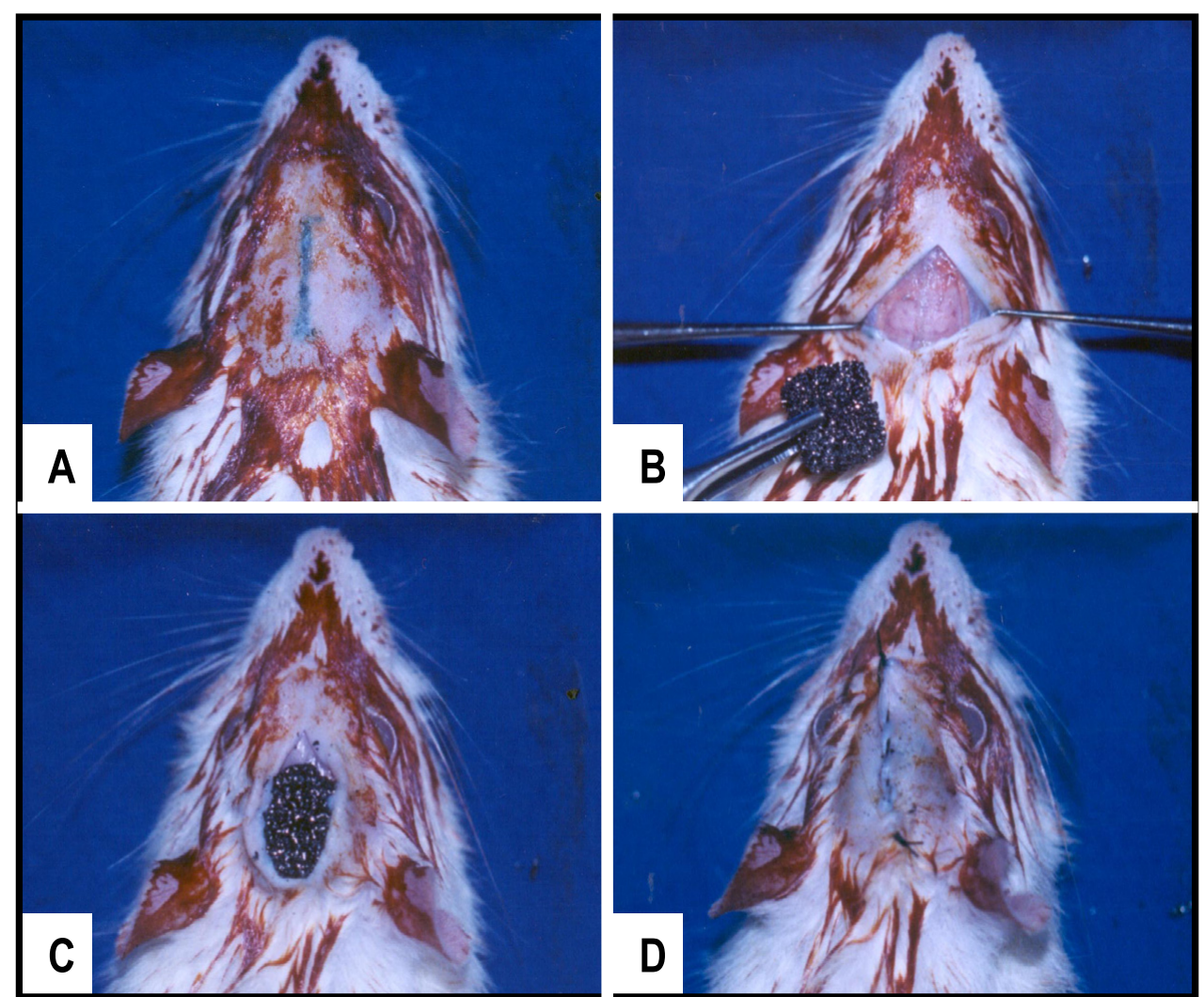

FIGURE 3 - Incision (A) for access to rat skull (B) allow to located the porous vitreous carbon $(\mathrm{C})$ and suture of the incision $(\mathrm{D})$

The analgesia was maintained with dipyrone, for a period of 15 days, starting it in the immediate postoperative period. anesthetic.

Euthanasia has been through deepening of the plan

Radiological studies were conducted through the heli-

\section{Procedures}

The animals were subjected to the anesthesia, $0.2 \mathrm{ml}$ ketamine hydrochloride associated with xylazine hydrochloride $2 \%, 0.1 \mathrm{ml}$, administered intramuscularly, trichotomy in the parietal region, ventral decubitus, anti-sepsis with iodopovidine topic, median incision, the muzzle to the back with knife blade 15 , divulsion of subcutaneous cellular tissue and muscle occipital - front, with iris scissors, access to the cranial calotte, periosteum detachment in the area of $1 \mathrm{~cm}^{2}$ in location median. Deployment by affixing, the fragment of carbon or silicon (as a group) in the central region and median, closing skin with wire monofilament polyamide 3.0 , end of the foregoing curative surgery (Figure 3). 
The deformity of the implants was evaluated by the presence or absence at the site of the greatest thickness of the implant in coronal cut.

The formation of capsule (pseudo-capsule) was evaluated in bone interfaces / implant and soft tissue / implant, by the presence or absence.

It was used the Hounsfield's scale ${ }^{9}$ for evaluation of the amendment radio density the implant by the presence or absence.

The radio density of implants was obtained through the marking of a point in choosing local representative of the implant, in the center and near the cranial calotte. The result containing radio density maximum, minimum, average and standard deviation was provided automatically, the program inserted in the system of computerized tomography of the device. $\left({ }^{*} \mathrm{Si}-\right.$ emens Somaton Espirit Plus)

Statistical analysis was performed by the Discipline of Biostatistics, Department of Preventive Medicine at the Federal University of Sao Paulo. They were used non - parametric tests, taking into consideration the nature of the variables studied:

1. Test Mann-Whitney ${ }^{10}$ with the aim of comparing separately for groups A and B, the values observed for seven and 28 days of euthanasia. The same test was applied in order to compare the groups A and B, separately for the 7th and the 28th day of euthanasia.

2. Testing of the chi-square test or the exact Fisher ${ }^{10}$, with purpose to compare, separately for groups A and B, periods of 7th and the 28th day of euthanasia on attendance or absence of various characteristics studied.

The same tests were applied, moreover, with the purpose of comparing the groups $\mathrm{A}$ and $\mathrm{B}$, separately for the 7 th and 28th day of euthanasia.

In all the tests set themselves on 0.05 or $5 \%$ the standard for rejection of the possibility of nullity ${ }^{10}, \leq 5 \%$ (a noting with a significant asterisk figures).

\section{Results}

After the operative procedures, the animals had a boss noticeable in the area of the implant due to the same place (Figure 4).

The seven days of post-operatively, the boss remained in the two groups. At 28 days was observed reduction in the volume of the implant in Group A. This fact was not observed in group B (Figure 5), except for four implants that were exposed, discharged and lost. In group A, for 28 days, there was an animal with the implant exposed, but this has not been expelled, remained attached to the cranial calotte mouse.

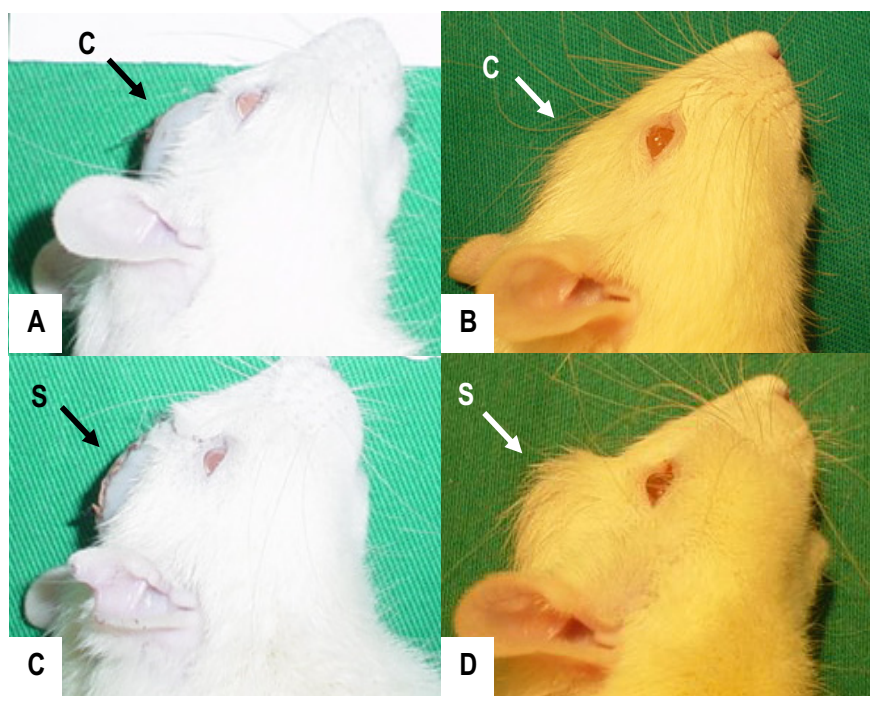

FIGURE 4 - Clinical evaluation of the boss in the area of the carbon or silicon implant

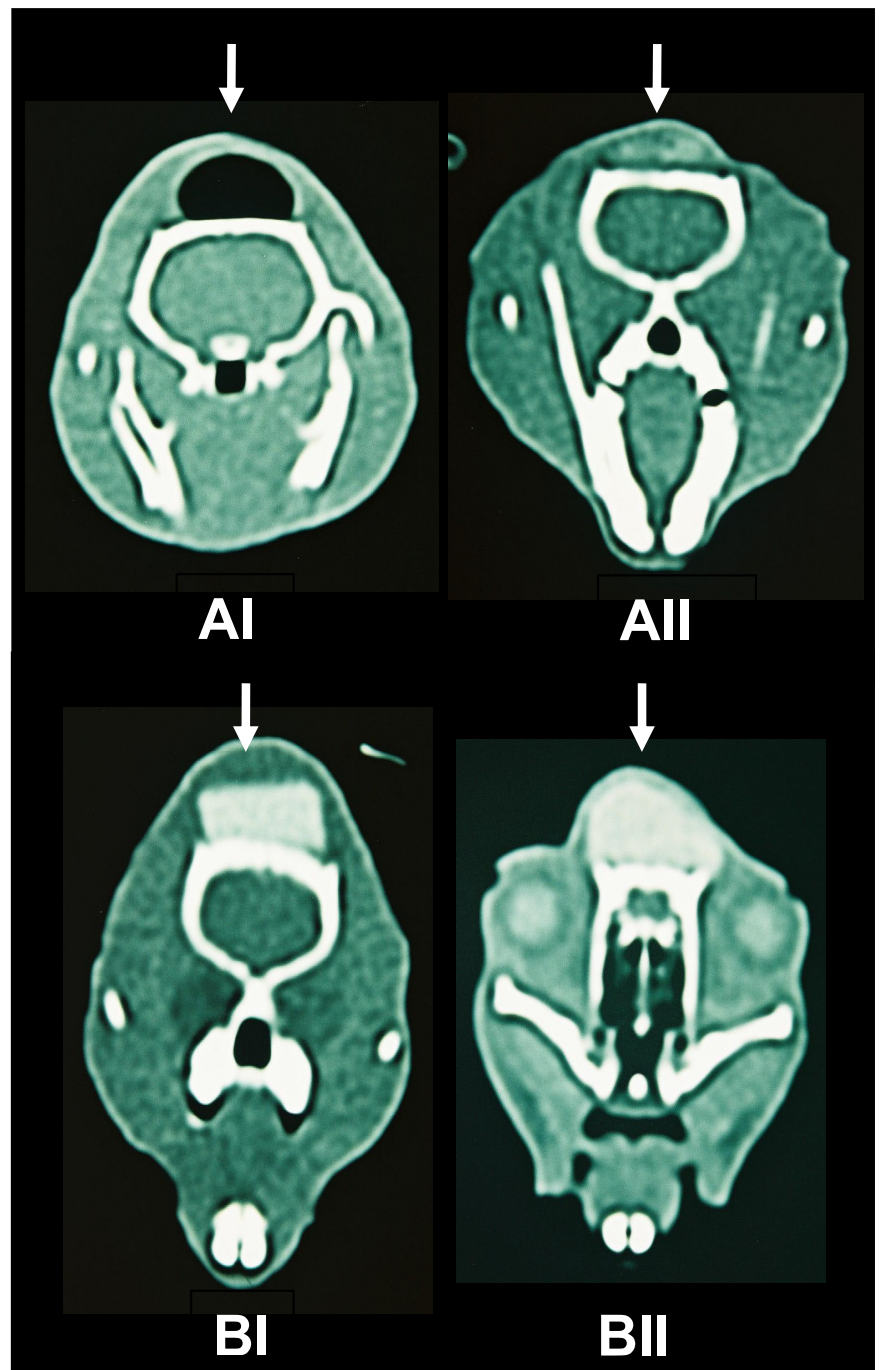

FIGURE 5 - Coronal Tomography images at seven (subgroups I) and 28 days (subgroups II) of post-operative, showing a reduction in the volume of the implant in the Group A. Group B maintaining volume and shape of the implant 
TABLE 1 - Rats subjected to implant according to the values of deformation of the implant

\begin{tabular}{clllll}
\hline & \multicolumn{2}{c}{ Group A } & & \multicolumn{2}{c}{ Group B } \\
\cline { 2 - 3 } \cline { 5 - 6 } 7 days & $\mathbf{2 8}$ days & & $\mathbf{7}$ days & $\mathbf{2 8}$ days \\
\hline 6 & 2 & & 8 & -- \\
4 & 3 & & 8 & -- \\
6 & 2 & & 8 & -- \\
6 & 4 & & 8 & -- \\
6 & 3 & & 8 & 8 \\
6 & 1 & & 8 & 8 \\
6 & 2 & & 8 & 8 \\
& 6 & 3 & & 8 & 8 \\
& 6 & 2 & & 8 & 8 \\
& 6 & 3 & & 8 & 8 \\
\hline Media & $\mathbf{5 . 8}$ & $\mathbf{2 . 5}$ & & $\mathbf{8 . 0}$ & $\mathbf{8 . 0}$ \\
Median & $\mathbf{6 . 0}$ & $\mathbf{2 . 5}$ & $\mathbf{8 . 0}$ & $\mathbf{8 . 0}$ \\
\hline
\end{tabular}

Mann-Whitney Test $-\mathrm{p}<0.05$

7 days $x 28$ days: Group $\mathbf{A}=7$ days $>28$ days; Group $\mathbf{B}=0,00$ NS

Group A x Group B: 7 days and 28 days: Group A $<$ Group B

TABLE 2 - Radiological variables in the implants, according to the presence (P) or absence (A) of pseudo-capsule and change of radio density

\begin{tabular}{|c|c|c|c|c|c|c|c|c|c|c|}
\hline \multirow{2}{*}{$\begin{array}{l}\text { Radiological } \\
\text { Variables }\end{array}$} & \multirow[b]{2}{*}{ Days } & \multicolumn{3}{|c|}{ Group A } & \multirow[b]{2}{*}{$\% \mathrm{P}$} & \multicolumn{3}{|c|}{ Group B } & \multirow[b]{2}{*}{$\% \mathrm{P}$} & \\
\hline & & $\mathbf{P}$ & A & Total & & $\bar{P}$ & A & Total & & \\
\hline \multirow{3}{*}{ Implant capsula } & 7 & 0 & 10 & 10 & 0.0 & 10 & 0 & 10 & 100.0 & $\chi^{2}=20.0^{*} A<B$ \\
\hline & 28 & 0 & 10 & 10 & 0.0 & 6 & 0 & 6 & 100.0 & $\tilde{P}=0.000^{*} A<B$ \\
\hline & $\overline{T \text { Total }}$ & $\begin{array}{l}0 \\
\text { No }\end{array}$ & $\begin{array}{l}20 \\
\text { anal }\end{array}$ & $\begin{array}{l}20 \\
y s i s\end{array}$ & 20.0 & & $\begin{array}{l}0 \\
\text { ana }\end{array}$ & $\begin{array}{l}16 \\
\text { ysis }\end{array}$ & 100.0 & $P=0.3526 \mathrm{NS}$ \\
\hline \multirow{3}{*}{$\begin{array}{l}\text { Change in } \\
\text { radiodensity }\end{array}$} & 7 & 0 & 10 & 10 & 0.0 & 0 & 10 & 0 & 100.0 & No analysis \\
\hline & 28 & 10 & 0 & 10 & 100.0 & 0 & 6 & 0 & 100.0 & $P=0.000^{*} A<B$ \\
\hline & Total & $\begin{array}{l}0 \\
P=\end{array}$ & $\begin{array}{l}20 \\
20 .\end{array}$ & $\begin{array}{l}20 \\
0^{*} 7<28\end{array}$ & 20.0 & & & $\begin{array}{l}0 \\
\text { ysis }\end{array}$ & 100.0 & $P=0.3526 \mathrm{NS}$ \\
\hline
\end{tabular}




\section{Discussion}

The need for material substitution occurs when the bone (autogenous bone), considered the best substitute is not available or accessible to the correction of defects with loss of bone substance ${ }^{2}$.

The carbon with medical usefulness can be made in three ways: vitreous, fiber or fiber reinforced with carbon ${ }^{4}$. We use the vitreous carbon with pores.

The silicon is a polymer with consistency of rubber ${ }^{5}$, used in our study in its solid form.

We seek a porous biomaterial, national, which could in future serve as a basis for crops cell (porous vitreous carbon). The silicon used for comparison because it is one of the most inert implants to the human been ${ }^{5,7,11,12}$ and is the most done in humans, especially women with aesthetic purposes ${ }^{12}$.

The silicon does not present osseous integration, and may even cause bone resorption as a radiological study that assessed their location and method of implantation ${ }^{13,14}$.

The carbon choused was presented porosity greater than 200 micra, enough to allow a bone growth. The implants for bone replacement should allow the growth of bone cells to their interior, because the penetration inside implant, occur in material with pore size greater than 100 micra $^{15}$.

Lewandowska - Szumiel et al. ${ }^{16}$ conducted study in the rat femur, using a carbon reinforced with pores of 30 micro and observed for growth within the bone implants, despite the smaller size of the pores in relation to previous studies ${ }^{17}$.

The conventional radiographic techniques present as radiological study of choice, in other studies ${ }^{18,19}$ on bone implants.

The images obtained in computed tomography, have more versatility because they can be studied in three dimensions, with a greater number of information, allowing better studies, even in small samples ${ }^{9}$. Due to these reasons, we opt for computed tomography (CT) in our study.

CT presents images based on the attenuation coefficient of the tissue in linear image obtained by radiography in a plan and then in combination of several plans; this attenuation coefficient is proportional to the density of the tissue and can be called radio density. These tissue radio densities were converted to a numerical scale, which can be called Range of Hounsfield ${ }^{9}$ with their respective units (UH).

The scale of Hounsfield sets the mitigation of air in $\mathrm{UH}-1000$, the water in zero $\mathrm{UH}$, the fatty tissue in approximately $100 \mathrm{in}-\mathrm{UH}$, the muscle tissue in about $40 \mathrm{UH}$, the spongy bone around $200 \mathrm{UH}$ and the cortical bone around $2000 \mathrm{UH} 25$. This scale was used to assess whether there was a change in attenuation coefficient, radio density of the implants.

In studies with $\mathrm{CT}$ noticed a different radio densities around all of silicone prostheses, which was characterized as radiological signal corresponding to pseudo-capsule; this signal not appeared in carbon implants.

The silicon has remained unchanged in the radiological study, but the carbon has had a modification in its radio density ( $\mathrm{p} \leq 0,05)$, in all implants. Our first impression after check images, was that could have been a growth of bone cells into the same, but the study histological comparison, it was observed that the increase in radio density due to the completion of implants by fibrosis.

These are a deformity of implants carbon to 28 days. The intense fibrosis could have been the cause of the deformity occurred, finishing the use of the implants as part of filling bone.

In implants carbon noticed that the fibrosis filled in the spaces between the bone and the implant and in the middle of it. This filling associated with lesion in the periosteum bed of the implant, may have been factors that hampered a bone growth into the implant.

In other studies with the carbon not was porous, were not observed deformities of the implants, which enabled their clinical use , $^{8,17-20}$.

Silicon implants in the presence of pseudo-capsule seems to have been the factor that impossible integration bone.

The results of the experiment showed two materials for implants with a biocompatibility adequate, that is, there was not a foreign body reaction type, but the porous carbon presented a great physical frailty, not allowing maintain their structure at the end of the period of study and presenting a change of radio density deformity with the implant.

The carbon evaluated with the physical structure is not provided by the replacement bone mechanical failures. The possibility of the manufacture of a structure of reinforced carbon, further studies with longer periods of assessment will be needed to reach a national porous carbon with more resistance to deformity.

\section{Conclusion}

From a radiological aspect the implants carbon porous vitreous have greater deformation that the silicon, which makes them not suitable for replacement of membranous bone in the craniofacial skeleton.

\section{References}

1. Vaccari-Mazzetti MP. Embriologia e crescimento da face. In: Carreirão S, Cardim V, Goldenberg D. Cirurgia Plástica. São Paulo: Atheneu; 2005. p. 211-27.

2. Habal MB, Reddi AH. Bone grafts and bone induction substitutes. Clin Plast Surg. 1994; 21(4):525-42.

3. Vaccari-Mazzetti MP, Martins DMF, Mauro LDL, Rocco M, Brock RS, Passini AP, Kobata CT, Labonia C. Síndrome de Goldenhar. Arq Cat Med. 2003; 32(s1):96-100.

4. Jenkins GM. Biomedical applications of carbons and graphite's. Clin Phys Physiol Meas. 1980; 1(3):171-94.

5. Blocksma R, Braley S. The silicon in plastic surgery. Plast Reconstr Surg. 1965; 35:366-70.

6. Patrocínio JA. O uso do implante de carbono na correção cirúrgica do nariz em sela [Tese Mestrado]. Universidade Federal de São Paulo: Escola Paulista de Medicina; 1985.

7. Mortellaro C, Garagiola U, Lucchina AG, Grivetto F, Milone $\mathrm{G}$. The use of silicon elastomer in maxilofacial rehabilitation as a substitute for or in conjunction with resins. J Craniofac Surg. 2006; 17(1):152-62. 
8. Iakimemko DV, Bellendir EN, Garbuz AE. Type uukm-4d carbonic carbon and porous titanium in plastic repair in bone defects: experimental studies. Probl Tuberk. 1999; 3:48-51. 9. Branemark PI, Hanson BO, Adell R. Using ct and implant to plan implant therapy. 2001. In: http://www.simplant.com/articles/omega.html.

10. Siegel S, Castellan Jr NJ. Nonparametric statistics. New York: McGraw-Hill; 1988.

11. Kafejian AP, Haddad Filho D, Guidugli Neto J, Goldenberg S. Estudo comparativo das reações teciduais à implantação de silicone e politetrafluoretileno no dorso de ratos. Acta Cir Bras. 1997; 12(3): 182-8

12. American Society of Plastic and Reconstructive Surgery. National Clearinghouse of Plastic Statistics; 2005. In: http:// www.plasticsurgery.org/mediactr/99nat.htm

13. Friedland JA, Coccaro PJ, Converse JM. Retrospective cephalometric analysis of mandibular bone absorption under silicon rubber chins implants. Plast Reconstr Surg. 1976; 57(2):144-51.

14. Saleh HA, Lohuis PJFM, Vuyk HD. Bone resorption after alloplastic augmentation of the mandible. Clin Otolaryngol.
2002; 27:129-32.

15. Wake MC, Patrick CW Jr, Mikos AG. Pore morphology effects in the fibrovascular tissue growth in porous polymer substrates. Cell Transplant. 1994; 3(4):339-43.

16. Lewandowska-Szumiel M, Komender J, Chlopek J. Interaction between carbon composites and bone after intrabone implantation. J Biomed Mater Res. 1999; 48:289-96.

17. Trantolo DJ, Sonis ST, Thompon BMJ, Wise DL, Lewandrowski KU, Hile DD. Evaluation of a porous, biodegradable biopolymer scaffold for mandibular reconstruction. Int J Oral Maxillofac Implants. 2003;18(2):182-8.

18. Mass CS, Merwin GE, Wilson J, Frey MD, Maves, MD. Comparison of biomaterials for facial bone augmentation. Arch Otolaryngol Head Neck Surg. 1990; 116(5):551-6.

19. Levine BR, Sporer S, Poggie RA, Della Valle CJ, Jacobs JJ. Experimental and clinical performance of porous tantalum in orthopedic surgery. Biomaterials. 2006; 27(27):4671-81.

20. Li H, Zou X, Woo C, Ding M, Lind M, Banger C. Experimental lumbar spine fusion with novel tantalum-coated carbon fiber implant. J Biomed Mater Res B Appl Biomater. 2007; 81(1):194-200.

\section{Correspondence:}

Conflict of interest: none Marcelo Vaccari

Av. Ceci, 475

04065-000 São Paulo - SP Brazil

mmgvaccari@ig.com.br

Received: November 19, 2007

Review: January 23, 2008

Accepted: February 19, 2008

\section{How to cite this article}

Vaccari-Mazzetti MP, Martins DMFS, Gomes PO, Martins JL, Fabiani P, Kobata CT. Evaluation of porous vitreous carbon or silicon implants by radiology in rat's skull. Acta Cir Bras. [serial on the Internet] 2008 May-June;23(3). Available from URL: http://www.scielo.br/acb

*Color figures available from www.scielo.br/acb 